\title{
Female Political Representation and Child Health: Evidence from a Multilevel Analysis
}

\author{
Amm Quamruzzaman, McGill University \\ Matthew Lange, McGill University
}

\section{Running Head}

Female Political Representation and Child Health

\section{Acknowledgements}

Quamruzzaman acknowledges funding from Fonds Québec de Recherche Société et Culture.

Lange's research for this article was financed by the Social Sciences and Humanities Research

Council of Canada.

\section{Corresponding author}

Amm Quamruzzaman

Department of Sociology, McGill University

855 Sherbrooke Street West, Room 712, Leacock Building

Montreal, Quebec, Canada H3A 2T7

Telephone: 1-514-291-5768

Email: amm.quamruzzaman@mail.mcgill.ca. 


\title{
Female Political Representation and Child Health: \\ Evidence from a Multilevel Analysis
}

\begin{abstract}
This article explores the impact of female political representation in national parliaments on child health through a multilevel analysis. Using available Demographic and Health Surveys, we employ both cross-sectional data for 51 low- and middle-income countries and longitudinal data for 20 countries with multiple surveys. For both the cross-sectional and longitudinal analyses, female representation is negatively related to infant mortality and positively related to measles vaccination status. To explore potential mechanisms, we control for state spending on health and analyze whether the impact of female representation depends on a critical mass of female representatives. The analysis offers evidence that state spending accounts for some of the mediation effect and that the impact of female representation on infant death depends on a critical mass.
\end{abstract}

Key words: female political representation; child health; state health spending; critical mass; multilevel analysis 


\section{Introduction}

Gender equality is an extremely important developmental goal in its own right, but there is evidence that it can also have beneficial externalities. Several analyses, for example, find that increases in female education have positive effects on child health (Caldwell 1986; Bledsoe et al. 1999; Sen 1999). More recently, there has been growing interest in analyzing how female representation in formal politics affects child health. Different studies on local politics in India find that increased female representation is associated with policies that improve the health of children (Bhalotra and Clots-Figueras 2011; Chattopadhyay and Duflo 2004). In a more general study, Swiss, Fallon, and Burgos (2012) complete statistical analyses of 102 developing countries over the period 1980-2005 and find that female representation is positively related to a variety of child health indicators, suggesting that increasing female participation in formal politics can have important health benefits for children.

While these studies offer important initial insight, they have limitations. The findings on local government in India, for example, cannot be extended to other settings. The cross-national findings, on the other hand, are based on aggregate data for health outcomes and ignore important individual-level variables such as mother's age, educational attainment, household socioeconomic status, and employment status. Without taking these individual-level factors into account, cross-national ecological studies may produce inaccurate results (Granvelle, Wildman, and Sutton 2002).

In this article, we build on previous studies to explore the impact of female political representation on two child health outcomes - infant death and measles vaccination statusamong a set of low- and middle-income countries (LMICs). To avoid potential problems caused 
by using only aggregate-level data, we complete a multilevel analysis using individual-level survey data on child health. For this, we join Inter-Parliamentary Union (2015) panel data on percentage of seats in national parliaments held by women to individual-level data from Demographic and Health Surveys (DHSs) for several LMICs. We also begin to explore potential mechanisms linking female representation to child health by testing the relationship between female political representation and state spending on health and exploring whether these effects depend on a critical mass of female representatives.

\section{Female Political Representation and Child Health: A Brief Review}

Demographic analyses commonly find that empowering women improves the health of children and suggest that a variety of mechanisms underlie the relationship. One potential mechanism is through greater access to information, such as information about the causes of illnesses, whether to seek assistance for a child's illness, how to treat an illness, and where to seek treatment (Barrera 1990; Hicks et al. 2006; Kickbusch 2001; Vandemoortele and Delamonica 2002). In addition, education commonly expands social networks, which are an important source of health information and support (Kawachi, Kennedy, and Glass 1999; Berkman and Glass 2000). Female empowerment can also increase female household authority (Desai and Johnson 2005; McGuire and Popkin 1990; Nussbaum 2000; Presser and Sen 2000), and the latter affects child health through several mechanisms: It can improve female diets during pregnancy (Kishor 2000; Osmani and Sen 2003), increase the resources available to children (Bloom, Wypij, and Das Gupta 2001; Caldwell 1986; Das Gupta 1990; Miles-Doan and Bisharat 1990), and give women greater influence in decisions about reproduction (Abadian 
1996; Jeffrey and Basu 1996; Bledsoe et al. 1999; Caldwell 1980; Visaria 1993). Finally, female empowerment can affect the care-giving ability of women by shaping their relationships outside the household (Ahmed, Creanga, Gillespie, and Tsui 2010; Ahmed, Thomson, Petzold, and Kabir 2005; Vissandjée, Barlow, and Fraser 1997).

At first glance, female empowerment through political representation would not appear to affect child health at a population level through any of these mechanisms, as only a minuscule fraction of the population is elected as representatives. Yet, increases in female political representation might affect the health of children at a population level in other more indirect ways. In this study, we focus on one potential mechanism related to social policy, exploring whether female representatives are more likely to support policy benefiting child health. Survey data on political attitudes suggest that women - relative to men-are more likely to support policies that seek to reduce gender inequities and improve social welfare, both of which positively affect child health (Everitt 2002; Gidengil 1995; Pratto, Stallworth, and Sidanius 1997; Shapiro and Mahajan 1986). Different studies, in turn, find that female politicians, on average, are more in favor of policies addressing gender inequities and social welfare (Bolzendahl 2009; Bolzendahl and Brooks 2007; Brady 2009; Caiazza 2004; Celis 2007; Childs 2002; TaylorRobinson and Heath 2003). Gender differences in support of female-friendly policies likely result from the fact that women experience gender inequities first-hand and are therefore more aware of their presence and consequences. Because of these differences, female representation might increase the chances of passing policy that empowers women. And as noted in the previous discussion, female empowerment potentially benefits child health in a variety of ways. Similarly, gendered norms and roles about childcare might increase female concern for the well- 
being of children, suggesting that female politicians are more concerned than their male counterparts about child vaccination programs, pre- and ante-natal care, safe motherhood, breastfeeding, and maternity leave policies (Jones 1997; Saint-Germain 1989; Welch 1985).

Although differential experience, norms, roles, and selective benefits potentially promote general differences in political attitudes between men and women, female politicians might also be more likely to support policy that directly and indirectly benefits child health because of selection effects. Most importantly, men and women might enter politics through different routes, and their different trajectories might affect their policy orientations. For example, more female politicians in the Global South enter politics via NGOs, women's movements, and community development whereas a larger percentage of male politicians come from more socially conservative backgrounds like law and business (Goetz 1997; Sinkkonen and HaavioMannila 1981). People with backgrounds in NGOs, women's movements, and community development might be more supportive of policy benefiting child health (Juusola-Halonen 1981).

\section{Data and Variables}

To explore whether female political representation improves child health outcomes, we complete cross-sectional and time-series analyses. Our data on female political representation come from the Inter-Parliamentary Union database on the percentage of parliamentary seats in a single or lower chamber of the national parliament held by women (Inter-Parliamentary Union 2015). Similar to Swiss, Fallon, and Burgos (2012), we use a 5-year lag of this variable because the implementation of policy affecting child health would likely take time to have its effects. We also test additional lags (e.g., 3-year, 8-year and 10-year). Using 3-year lag, we find similar 
results. As we increase the lag, however, we lose a large number of observations, which make the results somewhat inconsistent. Due to this, we report only the results obtained from the 5-year lag. All missing data have been dropped from the regression equations, using equal sample in Stata. In addition to using the 5-year lag, to look into a possible threshold effect, we also create three dummy variables measuring the levels of female representation: between 0 and 9.9 percent, between 10 and 19.9 percent, and 20 percent and greater, with 0 to 9.9 percent female representation as the reference category.

For control variables, we include several country-level controls that commonly affect child health and female empowerment. Four such variables come from the World Bank's (2016) World Development Indicators (WDI) database, and we use the natural logarithm of these variables: GDP per capita in 2011 constant international dollars (PPP adjusted), net official development assistance (ODA) per capita in current US dollars, female labor force participation rate as a percentage of the female population aged 15 and older, and female secondary gross enrollment ratio. We also include a dummy variable to indicate whether a left-leaning party controls the national parliament, as the orientations of leftist parties might promote both female representation and policy improving child health (Htun and Powers 2006). The dummy variable is coded as 1 if the political orientation of the largest government party is left of center and 0 otherwise, and is based on data from the Development Research Group at the World Bank (Beck et al. 2001). Next, we control for a country's extent of democracy because female representatives might be less able to influence policy affecting child health when the level of democracy is low (Ballington and Karam 2005). We measure the extent of democracy along a scale that ranges from 0 to 10, where 0 is least democratic and 10 most democratic. This variable is an average of 
Freedom House political rights and civil liberty and Polity IV modified polity measure, both transformed to a scale 0-10 and missing values are imputed. Finally, to explore our hypothesis that female representation affects child health through policy, we include a variable measuring public spending on health as a percentage of GDP. Specifically, we add this variable to see if its inclusion transforms the relationship between female representation and child health. The data come from the WDI database (World Bank 2016).

In addition to these country-level variables, we also control for individual-level factors that shape child health. All data on these variables come from Demographic and Health Surveys (2015) of LMICs. These individual-level controls include: sex of the child (male $=1$ ), year of child birth, mother's highest level of education, mother's age at the child birth (less than 20 years, 20-39 years and 40 years and above, with the age 20-39 years as the reference category), area of residence (urban $=1$ ), and socioeconomic status $(\mathrm{SES})$. Following the method suggested by Filmer and Pritchett (2001), DHS has constructed the SES index using available information on a household's ownership of selected assets (e.g., bicycle, radio, and television), type of water source and sanitation facilities available to the household, and materials used for constructing the house. For the analysis, we use five SES categories from the poorest (first quintile) to the richest (fifth quintile), with the poorest as the reference category.

We employ two different DHS measures of child health as dependent variables: infant death and measles vaccination status. Infant death is calculated using the five-year birth histories provided by women interviewed in the DHS. We create binary indicators for infant deaths to measure whether each child died before the age of one. Measles vaccination status is also a binary outcome, with 1 meaning the child received the vaccine, and 0 otherwise. 
Using these variables, we construct both cross-country and longitudinal datasets to explore the impact of female political representation on child health through a multilevel analysis. The cross-sectional dataset allows us to analyze more countries, whereas the longitudinal dataset allows us to investigate the effects over time and helps to address the issue of omitted-variable bias. The cross-sectional dataset includes 51 countries with a single DHS surveyed between 2005 and 2012. For the countries with multiple surveys during this period, we only include the latest survey. The longitudinal dataset includes 20 countries that had multiple DHS surveyed between 2003 and 2011, with child observations time-indexed by the child's year of birth. Since these surveys are conducted approximately every five years, we use at least two subsequent surveys to calculate infant deaths and measles vaccination status from mothers' past five-year birth histories at more than one point in time, thus covering a period from 2000 to 2007 for the year of child birth. See Table 1 for a list of the countries, the survey years, and the sample sizes for both the cross-sectional and longitudinal datasets.

\section{$<<<$ TABLE 1 NEAR HERE $\gg>$}

For both datasets, we use marginal effects from probit regression to model our binary outcome variables. In the probit model, the inverse standard normal distribution of the probability is modeled as a linear combination of the predictors. The probit regression coefficients give the change in the z-score or probit index for a one-unit change in the predictor. To calculate predicted probabilities, we use dprobit command in Stata 13 and report marginal effects only for easy interpretation of results. To estimate robust standard errors, we cluster all variables at the sample cluster level for each country. To account for the effects of time and 
country, we include child birth year and geographical regions of countries in random-effects probit models.

Additionally, we perform multilevel mixed-effects logistic regressions, using the longitudinal dataset and xtmelogit command in Stata. Since intercepts may vary across countries, and since the individual-level variables may have unequal slopes across countries, we consider a two-level mixed-effects modeling, in which individuals (level 1) are nested in countries (level 2). Mixed-effects logistic regressions estimate both fixed effects as unstandardized regression coefficients on the logit scale and random effects as a sum of variance and covariance parameters. Our 51-country cross-sectional dataset is not appropriate for the mixed-effects model because there is no within-country variation in the country-level variables for the individual-level outcomes, since the country-level data are only from one specific point in time. We therefore report only the probit regression results for the cross-sectional analysis but both the probit and mixed-effects logistic regression coefficients for the longitudinal analysis.

Table 2 provides the descriptive statistics of the variables we use in the analysis. Most notably, the mean probability of infant death in both the 51-country cross-sectional and the 20country longitudinal datasets is very close, 5.1 percent and 5.4 percent respectively. There is greater variation in terms of the mean probability of measles vaccination, which is 64.9 percent for the cross-sectional dataset and 83.0 percent for the longitudinal dataset.

\section{$<<<$ TABLE 2 NEAR HERE $>>>$}

Of all the variables included in the models, only two-GDP per capita and female secondary gross enrollment ratio-have relatively high pair-wise correlations $(r>0.7)$. We 
therefore put them in two separate models and then in the same models to see if they affect our estimates differently. Because including both in the same model does not adversely change the results, we only present the results of the models with both variables.

\section{Multilevel Cross-Sectional Analysis of Female Representation and Child Health}

We begin our analysis with the multilevel cross-sectional analyses of 51 LMICs with single surveys using probit regression with marginal effects. Table 3 presents the results of six different models using infant death as the dependent variable. The first model only includes our measure of female political representation, the second model adds all individual-level control variables, and the third model adds a variety of country-level controls and regional dummies (with Eastern Europe and post-Soviet Union as the reference category). Models 4, 5, and 6 are the same as the first three except for the addition of the variable measuring health spending. We include this variable in separate models to explore the extent to which the effect of female representation is transformed by state health spending. This section focuses on the results from the first three models; we discuss the results for the models including health spending in a subsequent section.

\section{$<<<$ TABLE 3 NEAR HERE $>>>$}

As shown in Table 3, we find a negative relationship between female representation and infant mortality. With the exception of Model 2, the results show that increased female political representation in national parliaments significantly reduces the probability of infant death. Specifically, an increase in female political representation by one percentage point decreases the marginal probability of infant death by 0.02 percent when holding all other variables constant (in 
the full model). Alternatively, an increase in female representation by one standard deviation (10 percent) is associated with a decrease in the marginal probability of infant mortality by 0.2 percent. Because the average probability of infant death is 5.1 percent among our sample, this marginal effect—although small—is still substantially important.

Individual-level variables measuring mother's education and age, sex of child, household SES, and year of birth are all significantly related to infant deaths in the expected directions (in the full model). With one partial exception, the country-level controls of politics, economics, and female empowerment are also significantly related in expected directions. The exception is left-leaning party, which is positively related to infant death. This finding is contrary to expectations but similar to past findings. Among the regional control variables, only two are significantly different from Eastern Europe and the former Soviet Republics: The Middle East and North Africa (MENA) region has lower levels of infant death, and sub-Saharan Africa (SSA) has higher levels of infant death.

Table 4 replicates the models of Table 3 but uses measles vaccination status as the dependent variable. In all models, female political representation increases the prevalence of measles vaccination among children. Specifically, while holding all other variables constant, an increase in female political representation by one percentage point increases the marginal probability of child measles vaccination by between 0.3 and 0.8 percent. Relative to the models of infant death, fewer individual-level controls are related to measles vaccination: Mother's education and SES level are positively related to measles vaccination in all models, and year of birth is consistently negatively related to measles vaccination status. Mother's age at birth is negatively associated with measles vaccination status if she is over 40 , but positively associated 
if she is below 20. Child's sex is not significantly associated with measles vaccination. The relationships with the country-level controls are similar to those in Table 3 except for democracy and female secondary gross enrollment ratio, which are negatively related to measles vaccination status. As we include the regional dummies in the model (not shown in Table 3), female gross enrollment ratio changes direction from positive to negative, likely due to lower female gross enrollment ratio in MENA and sub-Saharan Africa compared to other regions. All regional controls are significantly related to measles vaccination status, with Latin America and the Caribbean and sub-Saharan Africa having lower levels of measles vaccination than Eastern Europe and the former Soviet Union, and the MENA and Asia having higher levels.

$$
<<<\text { TABLE } 4 \text { NEAR HERE } \gg>
$$

\section{Longitudinal Analysis of Female Representation and Child Health}

Our second set of multilevel models use longitudinal data for the 20 countries with multiple DHSs. Specifically, the models compare data from the same country at different times and explore whether within-country changes in female representation over time are related to changes in child health. The longitudinal analysis uses the same models as those used in the cross-sectional analysis in Tables 3 and 4.

Tables 5 and 6 present the results of the longitudinal analysis for infant death and measles vaccination status, respectively, using marginal effects for probit regression. Focusing on models 1,2 , and 3 of both tables, the results show a significant negative relationship between female political representation and infant mortality across all models. Yet, relative to the cross-sectional results in Table 3, female representation has a much larger impact on infant death in the full 
model, where an increase in female representation in national parliaments by one percentage point decreases the marginal probability of infant death by 0.1 percent. Given the average infant mortality rate among our sample (5.4 percent), this marginal effect is substantial. For measles vaccination, the results remain strong and consistent in all models.

To account for the hierarchical structure of our data, in which intercepts may vary across countries and the individual-level variables may have unequal slopes across countries, we also perform multilevel mixed-effects logistic regressions using the longitudinal dataset. The mixedeffects regression results (given in Tables A and B in the Appendix) confirm the results of our probit analysis presented in Tables 5 and 6, with female representation being consistently related to child health. The only major difference is that female representation loses its significance in the model of measles vaccination status when only including individual-level controls.

\section{$<<<$ TABLES 5 \& 6 NEAR HERE $>>$}

\section{Female Representation, Health Spending, and Child Health}

In this section, we analyze whether public health spending mediates the impact of female representation on child health. For this, we compare the first three models in Tables 3, 4, 5, and 6 to the final three models in the same tables, as the final models add a variable measuring public health spending. Although the difference varies from model to model, the results show that the addition of the health spending variable weakens the relationship between female representation and child health. In most models, however, female representation remains significantly related to both child health outcomes. To explore whether the mediation effect is significant, we complete Sobel tests (Baron and Kenny 1986; Sobel 1982). The results show that health spending is a 
significant mediator between female representation and child health in all models for both the cross-sectional and longitudinal analyses. Our results therefore suggest that health spending mediates the relationship between female representation and child health but that health spending only accounts for part of the relationship.

\section{Threshold Analysis for Critical Mass and Child Health}

While highlighting general relationships, the impact of female political representation might depend on a high number of female representatives in the national parliament. If a critical mass of women is necessary for female politicians to affect child health, we should see a nonlinear relationship between female representation and child health, with female representation only becoming influential after their numbers have reached a particular threshold. Consequently, if the threshold is high, the dummy measuring moderate levels of female political representation (10 to 19.9 percent) should be weakly related, but the dummy measuring high levels (20 percent and greater) should be strongly related to child health outcomes. Alternatively, if the threshold is lower, the dummies measuring moderate and high levels of female political representation should both have similar relationships with child health.

\section{$<<<$ TABLE 7 NEAR HERE $\gg>$}

Table 7 only presents the results of the full models for both the cross-sectional and longitudinal analyses using infant death and measles vaccination status as the dependent variables. We do not present other models because the patterns are similar to the full models. The findings for infant death support claims of a relatively high threshold effect: The dummy measuring moderate levels of female representation is not significantly related in either the 
cross-sectional or longitudinal analyses, whereas the dummy measuring high levels of female representation is strongly and negatively related to infant death in both analyses. The results for measles vaccination status are more mixed, however. For the cross-sectional analysis, the dummies measuring moderate levels of female representation have slightly higher coefficients than the dummies measuring high levels of female representation. The results of the longitudinal analysis, on the other hand, offer evidence for a stronger threshold effect: The coefficient of the dummy for the higher levels of female representation is almost twice as big as that of the dummy for moderate levels of female representation. While considerable, this difference is much smaller than in the models using infant death as the dependent variable: The coefficient of the dummy for high levels of female representation is more than six times greater than the dummy measuring moderate levels of representation when using infant death as the dependent variable. As such, the results suggest a strong threshold effect for infant death but offer evidence a lower threshold for measles vaccination.

\section{Conclusion}

This article offers evidence that female political representation benefits child health. Specifically, it finds that female political representation is negatively related to infant death and positively related to measles vaccination status. These findings are similar to those of previous studies, but our analysis expands on previous works by completing a multilevel analysis with individual-level data on child health for several countries. Such an analysis helps to avoid possible inaccuracies resulting from aggregating data on child health. We include both crosssectional analyses of 51 countries and longitudinal analyses of 20 countries. While the cross- 
sectional analyses include more countries and thereby offer greater insight into generalizability, the longitudinal analyses explore within-country variation over time and limit omitted-variable bias.

We also make a contribution to the literature by exploring whether public health spending mediates this relationship. Although finding that female representation does affect child health through spending, the results suggest that health expenditure only explains part of the relationship between female representation and child health. More work is therefore needed to explore mechanisms linking female representation to child health. One additional mechanism that might underlie the relationship is role-model effect, with female political representation providing a symbol of empowerment that inspires other women (Beaman, Duflo, Pande, and Topalova 2012; Burnet 2011; Lawless 2004). Female politicians are public figures and offer evidence that women can succeed in politics and other social realms that are commonly maledominated. Such examples might increase the confidence and assertiveness of women and encourage them to more forcefully pursue their interests; it might also increase male acceptance of greater female empowerment.

Our analysis also considers whether a "critical mass" is needed for female politicians to influence policy on child health. Supporting past findings by Swiss, Fallon, and Burgos (2012), we find that a critical mass of females is needed for improvements in infant death. Alternatively, our findings suggest that a small number of female representatives can affect measles vaccination status. Theoretically, a lower threshold for measles vaccination status makes intuitive sense if female representation affects child health through policy. Male politicians might be more supportive of policies that-like measles vaccination-directly affect child 
health. Infant death, however, is shaped by both direct and indirect factors, and it is possible that male politicians are less willing to support some policies that affect child health more indirectly. Most notably, gender equity and female empowerment shape child health indirectly, but policies attempting to address these issues commonly face greater opposition from some male politicians (Gidengil 1995; Pratto, Stallworth, and Sidanius 1997). Such opposition, in turn, could require a larger number of female politicians to push through the policy, suggesting the need for a critical mass of female representatives for infant death but not measles vaccination. These thoughts are only speculative, however, and additional research is needed to shed light on this issue.

Our analysis also has limitations that suggest the need for two additional areas of future research. First, while our use of probit and mixed-effects logistic models for the longitudinal analysis confirms our results and reduces the likelihood of omitted variable bias, it remains possible that the relationship is driven by other factors, such as the influence of international NGOs and donor communities working in the health field. Since the adoption of the Millennium Development Goal (MDG) framework in the year 2000, the global community has invested heavily in reducing child mortality, increasing female primary enrollment, and promoting gender equality. Particularly, the MDG initiatives have been very successful in increasing female primary enrollment and reducing child mortality in many LMICs (United Nations 2015). Concurrently, many countries have seen increases in female political representation or enacted legislation to guarantee female political representation (Dreher, Gehring, and Klasen 2015). These contextual features make it possible and even plausible that improvements in child health and female political representation have causes lying outside this analysis. One way to look into this issue is through qualitative analysis exploring mechanisms, such as case studies 
investigating whether female politicians are more supportive and more actively involved in policy affecting child health.

A second potential problem with our findings is the opposite of the first: Our analysis might underestimate the effect of female political representation on child health. We use a fiveyear lag and are unable to use longer lags because of missing data, but female political representation potentially affects child health in a variety of ways, some of which likely take considerably more than five years to have their full effect. For example, it is possible that female political representation positively affects female education, but such an effect would take a considerable period of time to come to fruition: It would take time to pass policy leading to greater female education, additional time for the implementation of such policies, and an additional five to fifteen years for the expansion of female education to affect child health. If multiple lags of different length do exist, our findings are likely more accurate for measles vaccination (for which we find a stronger and more consistent relationship with female representation), as the infant death is much more dependent on longer-term processes. Over the next decade, new data should allow researchers to employ longer lags and thereby offer insight into this possibility.

To summarize, this article offers additional evidence that expanding female political representation has positive effects on child health outcomes and that a critical mass is needed for female politicians to influence some child health outcomes. These findings support past analyses but offer new and improved insight by using multilevel models and highlighting public health spending as one mechanism underlying the relationship between female representation and child 
health. This area of research remains understudied, however, and additional research is still needed to shed light on this important issue. 


\section{References}

Abadian, S. 1996. "Women's Autonomy and Its Impact on Fertility." World Development 24(12):1793-1809.

Ahmed, S., A. A. Creanga, D. G. Gillespie, and A. O. Tsui. 2010. "Economic Status, Education and Empowerment: Implications for Maternal Health Service Utilization in Developing Countries." PloS one 5(6):e11190.

Ahmed, S. M., G. Tomson, M. Petzold, and Z. N. Kabir. 2005. "Socioeconomic Status Overrides Age and Gender in Determining Health-Seeking Behaviour in Rural Bangladesh.” Bulletin of the World Health Organization 83(2):109-117.

Ballington, J., and A. M. Karam, eds. 2005. Women in Parliament: Beyond Numbers. Stockholm: Trydells Tryckery AB.

Baron, R. M., and D. A. Kenny. 1986. "The Moderator-Mediator Variable Distinction in Social Psychological Research: Conceptual, Strategic, and Statistical Considerations.” Journal of Personality and Social Psychology 51(6):1173-1182.

Barrera, A. 1990. “The Role of Maternal Schooling and Its Interaction with Public Health Programs in Child Health Production.” Journal of Development Economics 32(1):69-91.

Bhalotra, S., and I. Clots-Figueras. 2011. "Health and the Political Agency of Women." Discussion Paper 6216. Bonn, Germany: Institute for the Study of Labor (IZA).

Beaman, L., E. Duflo, R. Pande, and P. Topalova. 2012. "Female Leadership Raises Aspirations and Educational Attainment for Girls: A Policy Experiment in India." Science 335 (February):582-586. 
Beck, T., G. Clarke, A. Groff, P. Keefer, and P. Walsh. 2001. "New Tools in Comparative Political Economy: The Database of Political Institutions.” World Bank Economic Review 15(1):165-176.

Berkman, L. F., and T. Glass. 2000. "Social Integration, Social Networks, Social Support and Health.” Pp. 138-173 in Social Epidemiology, edited by L. Berkman and I. Kawachi. New York: Oxford University Press.

Bledsoe, C. H., J. B. Casterline, J. A. Johnson-Kuhn, and J. G. Haaga, eds. 1999. Critical Perspectives on Schooling and Fertility in the Developing World. Washington, DC: National Academy Press.

Bloom, S. S., D. Wypij, and M. Das Gupta. 2001. "Dimensions of Women's Autonomy and the Influence on Maternal Health Care Utilization in a North Indian City.” Demography 38:67-78.

Bolzendahl, C. 2009. "Making the Implicit Explicit: Gender Influences on Social Spending in Twelve Industrialized Democracies, 1980-99." Social Politics 16(1):40-81.

Bolzendahl, C. and C. Brooks. 2007. "Women's Political Representation and Welfare State Spending in 12 Capitalist Democracies." Social Forces 85(4):1509-34.

Brady, D. 2009. Rich Democracies, Poor People: How Politics Explains Poverty. New York: Oxford University Press.

Burnet, J. E. 2011. “Women Have Found Respect: Gender Quotas, Symbolic Representation, and Female Empowerment in Rwanda." Politics \& Gender 7(03):303-34.

Caiazza, A. 2004. "Does Women's Representation in Elected Office Lead to Women-Friendly Policy? Analysis of State-Level Data." Women and Politics 26(1):35-70. 
Caldwell, J. C. 1980. "Mass Education as a Determinant of the Timing of Fertility Decline." Population and Development Review 6(2):225-255.

Caldwell, J. C. 1986. "Routes to Low Mortality in Poor Countries." Population and Development Review 12:171-220.

Celis, K. 2007. “Substantive Representation of Women: The Representation of Women's Interests and the Impact of Descriptive Representation in the Belgian Parliament (19001979).” Journal of Women, Politics and Policy 28(2):85-114.

Childs, S. 2002. New Labour's Women MPs: Women Representing Women. London: Routledge.

Chattopadhyay, R., and E. Duflo. 2004. "Women as Policy Makers: Evidence from a Randomized Policy Experiment in India.” Econometrica 72(5):1409-1443.

Dahlerup, D. 1988. "From a Small to a Large Minority: Women in Scandinavian Politics." Scandinavian Political Studies 11(2):275-98.

Das Gupta, M. 1990. "Death Clustering, Mother's Education, and the Determinants of Child Mortality in Rural Punjab, India.” Population Studies 44:489-505.

Desai, S., and K. Johnson. 2005. "Women's Decision Making and Child Health: Familial and Social Hierarchies.” Pp. 55-67 in A Focus on Gender: Collected Papers on Gender Using DHS Data, edited by S. Kishor. Calverton, MD, USA: Macro International.

DHS Program. 2015. "Demographic and Health Surveys.” Retrieved January 12, 2015 (http://dhsprogram.com/Data/).

Dreher, A., K. Gehring, and S. Klasen. 2015. "Gesture Politics or Real Commitment? Gender Inequality and the Allocation of Aid." World Development 70:464-480. 
Everitt, J. 2002. “Gender Gaps on Social Welfare Issues: Why Do Women Care?” Pp. 110-125 in Citizen Politics: Research and Theory in Canadian Political Behaviour, edited by Joanna. Everitt and B. O’Neill. New York: Oxford University Press.

Filmer, D. and L. H. Pritchett. 2001. "Estimating Wealth Effects without Expenditure Data - or Tears: An Application to Educational Enrollments in States of India." Demography 38(1):115-132.

Gidengil, E. 1995. "Economic Man - Social Woman? The Case of the Gender Gap in Support for the Canada-United States Free Trade Agreement." Comparative Political Studies 28(3):384-408.

Goetz, A. M., ed. 1997. Getting Institutions Right for Women in Development. London: Zed Books.

Granvelle, H., J. Wildman, and M. Sutton. 2002. "Income, Income Inequality and Health: What Can We Learn from Aggregate Data?" Social Science \& Medicine 54:577-589.

Hicks, G., M. Barragan, C. Franco-Paredes, M. Williams, and C. del Rio. 2006. "Health Literacy is a Predictor of HIV/AIDS Knowledge." Health Services Research 38(10):717-723.

Htun, M., and T. J. Powers. 2006. "Gender Parties, and Support for Equal Rights in the Brazilian Congress." Latin American Politics and Society 48(4): 83-104.

Inter-Parliamentary Union. 2015. "Women in National Parliaments." Retrieved January 12, 2015 (http://www.ipu.org/wmn-e/world.htm).

Jeffrey, R. and A. Basu, eds. 1996. Girls Schooling, Autonomy and Fertility Change in South Asia. New Delhi: Sage Publications. 
Jones, M. P. 1997. "Legislator Gender and Legislator Policy Priorities in the Argentine Chamber of Deputies and the United States House of Representatives." Policy Studies Journal 25:613-629.

Juusola-Halonen, E. 1981. “The Women's Liberation Movement in Finland.” Women's Studies International Quarterly 4(4):453-460.

Kawachi, I., B. Kennedy, and R. Glass. 1999. "Social Capital and Self-Rated Health: A Contextual Analysis." American Journal of Public Health 89(8):1187-1193.

Kickbusch, I. 2001. "Health Literacy: Addressing the Health and Education Divide." Health Promotion International 16(3):289-297.

Kishor, S. 2000. "Empowerment of Women in Egypt and Links to the Survival of Their Infants." Pp. 119-157 in Women's Empowerment and Demographic Processes: Moving beyond Cairo, edited by H. Presser and G. Sen. New York: Oxford University Press.

Lawless, J. L. 2004. "Politics of Presence? Congresswomen and Symbolic Representation." Political Research Quarterly 57(1):81-99.

McGuire, J. and B. M. Popkin. 1990. "Beating the Zero-Sum Game: Women and Nutrition in the Third World." Food and Nutrition Bulletin 12(1):3-11.

Miles-Doan, R. and L. Bisharat. 1990. "Female Autonomy and Child Nutritional Status: The Extended Family Residential Unit in Amman, Jordan.” Social Science \& Medicine 31:783-89.

Nussbaum, M. C. 2000. Women and Human Development: The Capabilities Approach. New York: Cambridge University Press. 
Osmani, S., and A. Sen. 2003. "The Hidden Penalties of Gender Inequality: Fetal Origins of IllHealth.” Economics \& Human Biology 1(1):105-121.

Pratto, F., L. Stallworth, and J. Sidanius. 1997. "The Gender Gap: Differences in Political Attitudes and Social Dominance Orientation.” British Journal of Social Psychology $36: 49-68$.

Presser, H., and G. Sen, eds. 2000. Women's Empowerment and Demographic Processes: Moving beyond Cairo. New York: Oxford University Press.

Saint-Germain, M. A. 1989. "Does their Difference Make a Difference? The Impact of Women on Public Policy in the Arizona Legislature." Social Science Quarterly 70:956-968.

Sen, A. 1999. Development as Freedom. New York: Anchor Books.

Shapiro, R. Y. and H. Mahajan. 1986. "Gender Differences in Policy Preferences: A Summary of Trends from the 1960s to the 1980s." Public Opinion Quarterly 50:42-61.

Sinkkonen, S. and E. Haavio-Mannila. 1981. “The Impact of the Women's Movement and Legislative Activity of Women MPs on Social Development.” Pp. 195-215 in Women, Power and the Political System, edited by M. Rendel. London: Croom Helm.

Sobel, M. E. 1982. “Asymptotic Intervals for Indirect Effects in Structural Equations Models.” Pp. 290-312 in Sociological Methodology, edited by S. Leinhart. San Francisco: JosseyBass.

Swiss, L., K. Fallon, and G. Burgos. 2012. "Does Critical Mass Matter? Women's Political Representation and Child Health in Developing Countries.” Social Forces 91(2):531-558.

Taylor-Robinson, M. M. and R. M. Heath. 2003. "Do Women Legislators have Different Policy Priorities than their Male Colleagues?” Women \& Politics 24(4):77-101. 
United Nations. 2015. The Millennium Development Goals Report 2015. New York: United Nations.

Vandemoortele, J. and E. Delamonica. 2002. "The 'Education Vaccine' Against HIV." Current Issues in Comparative Education 3(1):6-13.

Visaria, L. 1993. "Female Autonomy and Fertility Behaviour: An Exploration of Gujrat Data." Pp. 263-275 in Proceedings of International Population Conference of International Union for Scientific Study of Population, Montreal, Vol. 4. Liege, Belgium: IUSSP.

Vissandjée, B., R. Barlow, D. Fraser. 1997. “Utilization of Health Services among Rural Women in Gujarat, India." Public Health 111(3):135-48.

Welch, S. 1985. “Are Women more Liberal than Men in the U.S. Congress?” Legislative Studies Quarterly 10:125-134.

World Bank. 2016. "World Development Indicators." Retrieved August 16, 2016 (http://data.worldbank.org). 
Tables

Table 1. List of DHS countries with survey years and sample sizes

\begin{tabular}{|c|c|c|c|c|c|}
\hline \multicolumn{3}{|c|}{ 51-country cross-sectional dataset } & \multicolumn{3}{|c|}{ 20-country longitudinal dataset } \\
\hline Country & Survey year & $\begin{array}{r}\text { Sample } \\
\text { size }\end{array}$ & Country & Survey year & $\begin{array}{r}\text { Sample } \\
\text { size }\end{array}$ \\
\hline Albania & 2008 & 1650 & & & \\
\hline Armenia & 2010 & 1497 & Armenia & 2005 and 2010 & 2208 \\
\hline Azerbaijan & 2006 & 2344 & & & \\
\hline Bangladesh & 2011 & 8913 & Bangladesh & $2004,2007,2011$ & 11753 \\
\hline Benin & 2006 & 16322 & & & \\
\hline Bolivia & 2008 & 8748 & Bolivia & 2003 and 2008 & 13539 \\
\hline Burkina Faso & 2010 & 15275 & & & \\
\hline Burundi & 2010 & 7842 & & & \\
\hline Cambodia & 2010 & 8358 & Cambodia & 2005 and 2010 & 13373 \\
\hline Cameroon & 2011 & 11918 & & & \\
\hline Colombia & 2010 & 18041 & Colombia & 2005 and 2010 & 26852 \\
\hline Congo, Republic & 2011 & 9134 & & & \\
\hline Congo, Dem. Rep. & 2007 & 9439 & & & \\
\hline Cote d'Ivoire & 2011 & 7930 & & & \\
\hline Dominican Rep. & 2007 & 11341 & & & \\
\hline Egypt & 2008 & 11022 & Egypt & 2005 and 2008 & 18384 \\
\hline Ethiopia & 2011 & 11858 & & & \\
\hline Gabon & 2012 & 6164 & & & \\
\hline Ghana & 2008 & 3032 & Ghana & 2003 and 2008 & 5021 \\
\hline Guyana & 2009 & 2206 & & & \\
\hline Haiti & 2012 & 7355 & & & \\
\hline Honduras & 2011 & 11064 & Honduras & 2005 and 2011 & 17337 \\
\hline India & 2005 & 52385 & & & \\
\hline Indonesia & 2012 & 18309 & & & \\
\hline Jordan & 2012 & 10512 & & & \\
\hline Kenya & 2008 & 6148 & Kenya & 2003 and 2008 & 9547 \\
\hline Lesotho & 2009 & 4044 & Lesotho & 2004 and 2009 & 5777 \\
\hline Liberia & 2007 & 5869 & & & \\
\hline Madagascar & 2008 & 12657 & Madagascar & 2003 and 2008 & 15457 \\
\hline Malawi & 2010 & 20295 & Malawi & 2004 and 2010 & 25166 \\
\hline Maldives & 2009 & 3859 & & & \\
\hline Mali & 2006 & 14468 & & & \\
\hline Mozambique & 2011 & 11255 & & & \\
\hline Namibia & 2006 & 5243 & & & \\
\hline Nepal & 2011 & 5397 & Nepal & 2006 and 2011 & 9336 \\
\hline
\end{tabular}




\begin{tabular}{|c|c|c|c|c|c|}
\hline \multicolumn{3}{|c|}{ 51-country cross-sectional dataset } & \multicolumn{3}{|c|}{ 20-country longitudinal dataset } \\
\hline Country & Survey year & $\begin{array}{r}\text { Sample } \\
\text { size }\end{array}$ & Country & Survey year & $\begin{array}{r}\text { Sample } \\
\text { size }\end{array}$ \\
\hline Niger & 2012 & 12763 & & & \\
\hline Nigeria & 2008 & 29058 & Nigeria & 2003 and 2008 & 32704 \\
\hline Pakistan & 2012 & 11960 & & & \\
\hline Peru & 2007 & 17502 & & & \\
\hline Philippines & 2008 & 6686 & Philippines & 2003 and 2008 & 10622 \\
\hline Rwanda & 2010 & 9142 & Rwanda & 2005 and 2010 & 14336 \\
\hline Sao Tome/Principe & 2008 & 1958 & & & \\
\hline Senegal & 2010 & 12489 & Senegal & 2005 and 2010 & 17975 \\
\hline Sierra Leone & 2008 & 5716 & & & \\
\hline Swaziland & 2006 & 2849 & & & \\
\hline Tajikistan & 2012 & 5095 & & & \\
\hline Tanzania & 2010 & 8125 & Tanzania & 2004 and 2010 & 13184 \\
\hline Timor-Leste & 2009 & 9916 & & & \\
\hline Uganda & 2011 & 8024 & Uganda & 2006 and 2011 & 13095 \\
\hline Zambia & 2007 & 6477 & & & \\
\hline Zimbabwe & 2010 & 5617 & Zimbabwe & 2005 and 2010 & 8027 \\
\hline Total sample & & 515271 & & & 283693 \\
\hline
\end{tabular}


Table 2. Descriptive statistics for multilevel analysis

\begin{tabular}{|c|c|c|c|c|c|c|}
\hline \multirow[t]{2}{*}{ Variable } & \multicolumn{3}{|c|}{ Cross-sectional sample (51) } & \multicolumn{3}{|c|}{ Longitudinal sample (20) } \\
\hline & Obs. & Mean & SD & Obs. & Mean & SD \\
\hline Infant death & 411029 & 0.051 & 0.220 & 283693 & 0.054 & 0.226 \\
\hline Measles vaccination & 470465 & 0.649 & 0.477 & 197583 & 0.830 & 0.375 \\
\hline Mother's education & 515187 & 1.072 & 0.925 & 283691 & 1.075 & 0.851 \\
\hline Age at birth: $<20$ & 515271 & 0.123 & 0.328 & 283693 & 0.129 & 0.335 \\
\hline Age at birth: 20-39 (ref.) & 515271 & 0.824 & 0.381 & 283693 & 0.820 & 0.384 \\
\hline Age at birth: $40+$ & 515271 & 0.053 & 0.224 & 283693 & 0.051 & 0.220 \\
\hline Male child & 515271 & 0.511 & 0.500 & 283693 & 0.510 & 0.500 \\
\hline SES1 (poorest, ref. cat.) & 515271 & 0.252 & 0.434 & 283693 & 0.268 & 0.443 \\
\hline SES2 & 515271 & 0.217 & 0.412 & 283693 & 0.226 & 0.418 \\
\hline SES3 & 515271 & 0.199 & 0.399 & 283693 & 0.194 & 0.396 \\
\hline SES4 & 515271 & 0.179 & 0.384 & 283693 & 0.168 & 0.374 \\
\hline SES5 (richest) & 515271 & 0.153 & 0.360 & 283693 & 0.143 & 0.350 \\
\hline Urban residence & 515271 & 0.336 & 0.472 & 283693 & 0.304 & 0.460 \\
\hline Female rep. (5-year lag) & 515271 & 14.014 & 8.846 & 187422 & 10.010 & 5.986 \\
\hline Female rep.: $<10 \%$ (ref.) & 506137 & 0.413 & 0.492 & 187422 & 0.577 & 0.494 \\
\hline Female rep.: 10-19.9\% & 506137 & 0.396 & 0.489 & 187422 & 0.360 & 0.480 \\
\hline Female rep.: $20 \%$ and up & 506137 & 0.191 & 0.393 & 187422 & 0.062 & 0.242 \\
\hline Health spend. (\% of GDP) & 515271 & 2.773 & 1.588 & 283693 & 2.775 & 1.312 \\
\hline Extent of democracy & 515271 & 6.310 & 2.015 & 283693 & 5.929 & 2.014 \\
\hline Left party in power & 515271 & 0.330 & 0.470 & 283693 & 0.148 & 0.356 \\
\hline ODA per capita & 515271 & 51.571 & 51.634 & 283693 & 37.223 & 26.020 \\
\hline GDP per capita & 515271 & 4040 & 3527 & 283693 & 3291 & 2694 \\
\hline Female labor force & 515271 & 57.549 & 18.858 & 283693 & 62.502 & 18.679 \\
\hline Female secondary GER & 515271 & 47.829 & 25.503 & 224912 & 41.899 & 25.939 \\
\hline Region: Eastern Europe & 515271 & 0.021 & 0.142 & 283693 & 0.008 & 0.088 \\
\hline Region: Latin America & 515271 & 0.148 & 0.355 & 283693 & 0.203 & 0.403 \\
\hline Region: MENA & 515271 & 0.042 & 0.200 & 283693 & 0.065 & 0.246 \\
\hline Region: SSA & 515271 & 0.546 & 0.498 & 283693 & 0.565 & 0.496 \\
\hline Region: South-East Asia & 515271 & 0.084 & 0.277 & 283693 & 0.085 & 0.278 \\
\hline Region: South Asia & 515271 & 0.160 & 0.367 & 283693 & 0.074 & 0.262 \\
\hline
\end{tabular}

Notes: Obs. = Observations; $\mathrm{SD}=$ Standard Deviation 
Table 3. Marginal effects from probit regressions of female representation (5-year lag) on infant death, using 51-country cross-sectional DHS data

\begin{tabular}{|c|c|c|c|c|c|c|}
\hline \multirow[b]{2}{*}{ Variables } & \multicolumn{6}{|c|}{ Infant death } \\
\hline & (1) & (2) & (3) & (4) & (5) & (6) \\
\hline Female representation & $\begin{array}{c}-0.0001 * * * * \\
(0.000)\end{array}$ & $\begin{array}{l}-0.0001 \\
(0.000)\end{array}$ & $\begin{array}{c}-0.0002 * * * \\
(0.000)\end{array}$ & $\begin{array}{c}-0.0001 * \\
(0.000)\end{array}$ & $\begin{array}{l}-0.0001 \\
(0.000)\end{array}$ & $\begin{array}{c}-0.0002 * * * * \\
(0.000)\end{array}$ \\
\hline Health spending & & & & $\begin{array}{c}-0.001 * * * \\
(0.000)\end{array}$ & $\begin{array}{l}-0.001 * \\
(0.000)\end{array}$ & $\begin{array}{l}0.0001 \\
(0.000)\end{array}$ \\
\hline Mother's education & & $\begin{array}{c}-0.014 * * * \\
(0.000)\end{array}$ & $\begin{array}{c}-0.006^{* * * *} \\
(0.001)\end{array}$ & & $\begin{array}{c}-0.013^{* * * *} \\
(0.000)\end{array}$ & $\begin{array}{c}-0.006^{* * * *} \\
(0.001)\end{array}$ \\
\hline Age at birth: $<20$ & & $\begin{array}{c}0.015 * * * \\
(0.001)\end{array}$ & $\begin{array}{c}0.016^{* * * *} \\
(0.001)\end{array}$ & & $\begin{array}{c}0.015 * * * \\
(0.001)\end{array}$ & $\begin{array}{c}0.016 * * * \\
(0.001)\end{array}$ \\
\hline Age at birth: $40+$ & & $\begin{array}{c}0.010 * * * \\
(0.002)\end{array}$ & $\begin{array}{c}0.010^{* * * *} \\
(0.002)\end{array}$ & & $\begin{array}{c}0.010 * * * \\
(0.002)\end{array}$ & $\begin{array}{c}0.010^{* * * *} \\
(0.002)\end{array}$ \\
\hline Male child & & $\begin{array}{c}0.008 * * * \\
(0.001)\end{array}$ & $\begin{array}{c}0.008 * * * \\
(0.001)\end{array}$ & & $\begin{array}{c}0.008 * * * \\
(0.001)\end{array}$ & $\begin{array}{c}0.008 * * * \\
(0.001)\end{array}$ \\
\hline SES2 & & $\begin{array}{c}0.000 \\
(0.001)\end{array}$ & $\begin{array}{l}-0.002^{*} \\
(0.001)\end{array}$ & & $\begin{array}{c}0.000 \\
(0.001)\end{array}$ & $\begin{array}{l}-0.002^{*} \\
(0.001)\end{array}$ \\
\hline SES3 & & $\begin{array}{c}0.001 \\
(0.001)\end{array}$ & $\begin{array}{c}-0.004 * * * \\
(0.001)\end{array}$ & & $\begin{array}{c}0.001 \\
(0.001)\end{array}$ & $\begin{array}{c}-0.004 * * * * \\
(0.001)\end{array}$ \\
\hline SES4 & & $\begin{array}{c}0.001 \\
(0.001)\end{array}$ & $\begin{array}{c}-0.008^{* * * *} \\
(0.001)\end{array}$ & & $\begin{array}{c}0.001 \\
(0.001)\end{array}$ & $\begin{array}{c}-0.008 * * * \\
(0.001)\end{array}$ \\
\hline SES5 (richest) & & $\begin{array}{l}-0.002 \\
(0.001)\end{array}$ & $\begin{array}{c}-0.015 * * * \\
(0.001)\end{array}$ & & $\begin{array}{l}-0.002 \\
(0.001)\end{array}$ & $\begin{array}{c}-0.015^{* * * *} \\
(0.001)\end{array}$ \\
\hline Urban residence & & $\begin{array}{c}-0.006 * * * * \\
(0.001)\end{array}$ & $\begin{array}{c}0.000 \\
(0.001)\end{array}$ & & $\begin{array}{c}-0.006 * * * \\
(0.001)\end{array}$ & $\begin{array}{c}0.000 \\
(0.001)\end{array}$ \\
\hline Year & & $\begin{array}{c}-0.001 * * * * \\
(0.000)\end{array}$ & $\begin{array}{c}-0.002 * * * \\
(0.000)\end{array}$ & & $\begin{array}{c}-0.001 * * * \\
(0.000)\end{array}$ & $\begin{array}{c}-0.002^{* * * *} \\
(0.000)\end{array}$ \\
\hline Extent of democracy & & & $\begin{array}{c}-0.002 * * * \\
(0.000)\end{array}$ & & & $\begin{array}{c}-0.002^{* * * *} \\
(0.000)\end{array}$ \\
\hline Left party in power & & & $\begin{array}{c}0.007 * * * * \\
(0.001)\end{array}$ & & & $\begin{array}{c}0.008^{* * * *} \\
(0.001)\end{array}$ \\
\hline Log ODA & & & $\begin{array}{c}-0.001 * * * \\
(0.000)\end{array}$ & & & $\begin{array}{c}-0.002 * * * \\
(0.000)\end{array}$ \\
\hline Log GDP $p c$ & & & $\begin{array}{c}-0.008^{* * * *} \\
(0.001)\end{array}$ & & & $\begin{array}{c}-0.008 * * * \\
(0.001)\end{array}$ \\
\hline Log female labor force & & & $\begin{array}{c}-0.018^{* * *} \\
(0.002)\end{array}$ & & & $\begin{array}{c}-0.018 * * * \\
(0.002)\end{array}$ \\
\hline Log female sec. GER & & & $\begin{array}{c}-0.006^{* * * *} \\
(0.001)\end{array}$ & & & $\begin{array}{c}-0.006^{* * * *} \\
(0.001)\end{array}$ \\
\hline
\end{tabular}




\begin{tabular}{|c|c|c|c|c|c|c|}
\hline Region: LAC & & & $\begin{array}{l}-0.000 \\
(0.003)\end{array}$ & & & $\begin{array}{l}-0.001 \\
(0.003)\end{array}$ \\
\hline Region: MENA & & & $\begin{array}{c}-0.022 * * * \\
(0.003)\end{array}$ & & & $\begin{array}{c}-0.022 * * * \\
(0.003)\end{array}$ \\
\hline Region: SSA & & & $\begin{array}{c}0.018 \text { *** } \\
(0.003)\end{array}$ & & & $\begin{array}{c}0.017 * * * \\
(0.003)\end{array}$ \\
\hline Region: SE Asia & & & $\begin{array}{c}0.007 \\
(0.004)\end{array}$ & & & $\begin{array}{c}0.006 \\
(0.004)\end{array}$ \\
\hline Region: South Asia & & & $\begin{array}{c}0.001 \\
(0.003)\end{array}$ & & & $\begin{array}{c}0.000 \\
(0.003)\end{array}$ \\
\hline Observations & 410,960 & 410,960 & 410,960 & 410,960 & 410,960 & 410,960 \\
\hline
\end{tabular}

Notes: Robust standard errors (SEs) in parentheses, clustered at the DHS sample cluster level; $* * * \mathrm{p}<0.001, * * \mathrm{p}<0.01, * \mathrm{p}<0.05 ;$ two-tailed tests. 
Table 4. Marginal effects from probit regressions of female representation (5-year lag) on measles vaccination status, using 51-country cross-sectional DHS data

\begin{tabular}{|c|c|c|c|c|c|c|}
\hline \multirow[b]{2}{*}{ Variables } & \multicolumn{6}{|c|}{ Measles vaccination status } \\
\hline & $(1)$ & $(2)$ & (3) & (4) & (5) & (6) \\
\hline Female representation & $\begin{array}{c}0.004 * * * \\
(0.000)\end{array}$ & $\begin{array}{c}0.007 * * * \\
(0.000)\end{array}$ & $\begin{array}{c}0.008 * * * \\
(0.000)\end{array}$ & $\begin{array}{c}0.003^{* * * *} \\
(0.000)\end{array}$ & $\begin{array}{c}0.005^{* * *} \\
(0.000)\end{array}$ & $\begin{array}{c}0.007 * * * \\
(0.000)\end{array}$ \\
\hline Health spending & & & & $\begin{array}{c}0.033 * * * \\
(0.001)\end{array}$ & $\begin{array}{c}0.042 * * * \\
(0.001)\end{array}$ & $\begin{array}{c}0.026^{* * *} \\
(0.001)\end{array}$ \\
\hline Mother's education & & $\begin{array}{c}0.080 * * * \\
(0.002)\end{array}$ & $\begin{array}{c}0.068 * * * \\
(0.002)\end{array}$ & & $\begin{array}{c}0.076^{* * * *} \\
(0.002)\end{array}$ & $\begin{array}{c}0.066 * * * \\
(0.002)\end{array}$ \\
\hline Age at birth: $<20$ & & $\begin{array}{l}0.009 * * \\
(0.003)\end{array}$ & $\begin{array}{c}0.012 * * * \\
(0.003)\end{array}$ & & $\begin{array}{l}0.008 * * \\
(0.003)\end{array}$ & $\begin{array}{c}0.013 * * * \\
(0.003)\end{array}$ \\
\hline Age at birth: $40+$ & & $\begin{array}{c}0.004 \\
(0.003)\end{array}$ & $\begin{array}{c}-0.018 * * * \\
(0.004)\end{array}$ & & $\begin{array}{c}0.000 \\
(0.004)\end{array}$ & $\begin{array}{c}-0.018 * * * \\
(0.004)\end{array}$ \\
\hline Male child & & $\begin{array}{c}0.002 \\
(0.001)\end{array}$ & $\begin{array}{c}0.002 \\
(0.001)\end{array}$ & & $\begin{array}{c}0.002 \\
(0.001)\end{array}$ & $\begin{array}{c}0.002 \\
(0.001)\end{array}$ \\
\hline SES2 & & $\begin{array}{c}0.026 * * * \\
(0.003)\end{array}$ & $\begin{array}{c}0.032 * * * \\
(0.003)\end{array}$ & & $\begin{array}{c}0.025^{* * *} \\
(0.003)\end{array}$ & $\begin{array}{c}0.030 * * * \\
(0.003)\end{array}$ \\
\hline SES3 & & $\begin{array}{c}0.047 * * * \\
(0.003)\end{array}$ & $\begin{array}{c}0.057 * * * \\
(0.003)\end{array}$ & & $\begin{array}{c}0.047 * * * \\
(0.003)\end{array}$ & $\begin{array}{c}0.055^{*} * * \\
(0.003)\end{array}$ \\
\hline SES4 & & $\begin{array}{c}0.061 * * * \\
(0.003)\end{array}$ & $\begin{array}{c}0.078 * * * \\
(0.003)\end{array}$ & & $\begin{array}{c}0.065^{* * *} \\
(0.003)\end{array}$ & $\begin{array}{c}0.076 * * * \\
(0.004)\end{array}$ \\
\hline SES5 (richest) & & $\begin{array}{c}0.093 * * * \\
(0.004)\end{array}$ & $\begin{array}{c}0.118 * * * \\
(0.004)\end{array}$ & & $\begin{array}{c}0.102^{* * *} \\
(0.004)\end{array}$ & $\begin{array}{c}0.116^{* * * *} \\
(0.004)\end{array}$ \\
\hline Urban residence & & $\begin{array}{c}-0.010 * * \\
(0.003)\end{array}$ & $\begin{array}{l}-0.005 \\
(0.003)\end{array}$ & & $\begin{array}{l}-0.007 * \\
(0.003)\end{array}$ & $\begin{array}{l}-0.001 \\
(0.003)\end{array}$ \\
\hline Year & & $\begin{array}{c}-0.039 * * * \\
(0.001)\end{array}$ & $\begin{array}{c}-0.060 * * * \\
(0.001)\end{array}$ & & $\begin{array}{c}-0.041 * * * \\
(0.000)\end{array}$ & $\begin{array}{c}-0.060 * * * \\
(0.001)\end{array}$ \\
\hline Extent of democracy & & & $\begin{array}{c}-0.015^{* * *} \\
(0.001)\end{array}$ & & & $\begin{array}{c}-0.020 * * * \\
(0.001)\end{array}$ \\
\hline Left party in power & & & $\begin{array}{c}-0.120 * * * \\
(0.004)\end{array}$ & & & $\begin{array}{c}-0.100 * * * * \\
(0.004)\end{array}$ \\
\hline Log ODA & & & $\begin{array}{c}0.054 * * * \\
(0.002)\end{array}$ & & & $\begin{array}{c}0.040 * * * \\
(0.002)\end{array}$ \\
\hline Log GDP pc & & & $\begin{array}{c}0.057 * * * \\
(0.003)\end{array}$ & & & $\begin{array}{c}0.063 * * * \\
(0.003)\end{array}$ \\
\hline Log female labor force & & & $\begin{array}{c}0.261 * * * \\
(0.008)\end{array}$ & & & $\begin{array}{c}0.262 * * * \\
(0.008)\end{array}$ \\
\hline Log female sec. GER & & & $\begin{array}{c}-0.057 * * * \\
(0.006)\end{array}$ & & & $\begin{array}{c}-0.085^{* * * *} \\
(0.006)\end{array}$ \\
\hline
\end{tabular}


Region: LAC

Region: MENA

Region: SSA

Region: SE Asia

Region: South Asia
$-0.096 * * *$

(0.013)

$0.235 * * *$

(0.008)

$-0.168 * * *$

(0.012)

$0.103 * * *$

$(0.012)$

$0.057 * * *$

(0.012)
$-0.139 * * *$

(0.013)

$0.191 * * *$

(0.010)

$-0.211 * * *$

(0.012)

$0.074 * * *$

(0.013)

$0.026^{*}$

(0.013)

\begin{tabular}{lllllll} 
Observations & 470,386 & 470,386 & 470,386 & 470,386 & 470,386 & 470,386 \\
\hline
\end{tabular}

Notes: Robust SEs in parentheses, clustered at the DHS sample cluster level; *** $\mathrm{p}<0.001$, ** $\mathrm{p}<0.01, * \mathrm{p}<0.05 ;$ two-tailed tests. 
Table 5. Marginal effects from probit regressions of female representation (5-year lag) on infant death, using 20-country longitudinal DHS data time-indexed by child's birth year over 2000-2007

\begin{tabular}{|c|c|c|c|c|c|c|}
\hline \multirow[b]{2}{*}{ Variables } & \multicolumn{6}{|c|}{ Infant death } \\
\hline & (1) & (2) & (3) & (4) & (5) & (6) \\
\hline Female representation & $\begin{array}{c}-0.0003^{* *} \\
(0.000)\end{array}$ & $\begin{array}{c}-0.0002^{*} \\
(0.000)\end{array}$ & $\begin{array}{c}-0.001 * * * \\
(0.000)\end{array}$ & $\begin{array}{l}-0.0002 \\
(0.000)\end{array}$ & $\begin{array}{c}-0.0002 \\
(0.000)\end{array}$ & $\begin{array}{c}-0.001 * * * * \\
(0.000)\end{array}$ \\
\hline Health spending & & & & $\begin{array}{c}-0.002 * * * \\
(0.000)\end{array}$ & $\begin{array}{c}-0.001 * * \\
(0.000)\end{array}$ & $\begin{array}{l}0.0004 \\
(0.001)\end{array}$ \\
\hline Mother's education & & $\begin{array}{c}-0.014 * * * * \\
(0.001)\end{array}$ & $\begin{array}{c}-0.007 * * * * \\
(0.001)\end{array}$ & & $\begin{array}{c}-0.014 * * * \\
(0.001)\end{array}$ & $\begin{array}{c}-0.007 * * * * \\
(0.001)\end{array}$ \\
\hline Age at birth: $<20$ & & $\begin{array}{c}0.015 * * * \\
(0.002)\end{array}$ & $\begin{array}{c}0.016 * * * \\
(0.002)\end{array}$ & & $\begin{array}{c}0.016^{* * * *} \\
(0.002)\end{array}$ & $\begin{array}{c}0.016^{* * * *} \\
(0.002)\end{array}$ \\
\hline Age at birth: $40+$ & & $\begin{array}{c}0.013 * * * \\
(0.003)\end{array}$ & $\begin{array}{c}0.013 * * * \\
(0.003)\end{array}$ & & $\begin{array}{c}0.013 * * * \\
(0.003)\end{array}$ & $\begin{array}{c}0.013 * * * \\
(0.003)\end{array}$ \\
\hline Male child & & $\begin{array}{c}0.010 * * * \\
(0.001)\end{array}$ & $\begin{array}{c}0.010^{* * * *} \\
(0.001)\end{array}$ & & $\begin{array}{c}0.010^{* * * *} \\
(0.001)\end{array}$ & $\begin{array}{c}0.010^{* * *} \\
(0.001)\end{array}$ \\
\hline SES2 & & $\begin{array}{c}0.002 \\
(0.002)\end{array}$ & $\begin{array}{l}-0.002 \\
(0.002)\end{array}$ & & $\begin{array}{c}0.002 \\
(0.002)\end{array}$ & $\begin{array}{l}-0.002 \\
(0.002)\end{array}$ \\
\hline SES3 & & $\begin{array}{c}0.003 \\
(0.002)\end{array}$ & $\begin{array}{l}-0.004 * \\
(0.002)\end{array}$ & & $\begin{array}{c}0.003 \\
(0.002)\end{array}$ & $\begin{array}{c}-0.004 * * \\
(0.002)\end{array}$ \\
\hline SES4 & & $\begin{array}{l}0.007 * * \\
(0.002)\end{array}$ & $\begin{array}{c}-0.006^{* * *} \\
(0.002)\end{array}$ & & $\begin{array}{c}0.007 * * \\
(0.002)\end{array}$ & $\begin{array}{c}-0.006^{* * *} \\
(0.002)\end{array}$ \\
\hline SES5 (richest) & & $\begin{array}{c}0.007 * * \\
(0.002)\end{array}$ & $\begin{array}{c}-0.012 * * * * \\
(0.002)\end{array}$ & & $\begin{array}{c}0.006^{* * *} \\
(0.002)\end{array}$ & $\begin{array}{c}-0.012^{* * * *} \\
(0.002)\end{array}$ \\
\hline Urban residence & & $\begin{array}{c}-0.011^{* * * *} \\
(0.001)\end{array}$ & $\begin{array}{c}0.002 \\
(0.002)\end{array}$ & & $\begin{array}{c}-0.011^{* * * *} \\
(0.001)\end{array}$ & $\begin{array}{c}0.002 \\
(0.002)\end{array}$ \\
\hline Year & & $\begin{array}{c}-0.002^{* * * *} \\
(0.000)\end{array}$ & $\begin{array}{c}-0.001 * * \\
(0.000)\end{array}$ & & $\begin{array}{c}-0.001 * * * \\
(0.000)\end{array}$ & $\begin{array}{c}-0.001^{* * *} \\
(0.000)\end{array}$ \\
\hline Extent of democracy & & & $\begin{array}{c}-0.002 * * * \\
(0.000)\end{array}$ & & & $\begin{array}{c}-0.002 * * * \\
(0.000)\end{array}$ \\
\hline Left party in power & & & $\begin{array}{c}0.017 * * * \\
(0.003)\end{array}$ & & & $\begin{array}{c}0.016^{* * * *} \\
(0.003)\end{array}$ \\
\hline Log ODA & & & $\begin{array}{l}-0.000 \\
(0.001)\end{array}$ & & & $\begin{array}{l}-0.000 \\
(0.001)\end{array}$ \\
\hline Log GDP pc & & & $\begin{array}{c}-0.008^{* * * *} \\
(0.002)\end{array}$ & & & $\begin{array}{c}-0.007 * * * \\
(0.002)\end{array}$ \\
\hline Log female labor force & & & $\begin{array}{c}-0.032^{* * * *} \\
(0.005)\end{array}$ & & & $\begin{array}{c}-0.033^{* * * *} \\
(0.005)\end{array}$ \\
\hline
\end{tabular}


Log female sec. GER

$-0.005^{*}$

(0.003)

Region: LAC

Region: MENA

Region: SSA

Region: SE Asia

Region: South Asia
0.006

(0.021)

$-0.020$

$(0.014)$

$0.039 *$

$(0.018)$

0.025

$(0.027)$

0.035

(0.030)
$-0.005^{*}$

(0.003)

0.005

$(0.021)$

$-0.021$

(0.014)

$0.039 *$

$(0.018)$

0.026

$(0.027)$

0.037

(0.030)

Observations

$152,804 \quad 152,804$

$152,804 \quad 152,804$

152,804

152,804

Notes: Robust SEs in parentheses, clustered at the DHS sample cluster level; *** $\mathrm{p}<0.001$, ** $\mathrm{p}<0.01, * \mathrm{p}<0.05 ;$ two-tailed tests. 
Table 6. Marginal effects from probit regressions of female representation (5-year lag) on measles vaccination status, using 20-country longitudinal DHS data time-indexed by child's birth year over 2000-2007

\begin{tabular}{|c|c|c|c|c|c|c|}
\hline \multirow[b]{2}{*}{ Variables } & \multicolumn{6}{|c|}{ Measles vaccination status } \\
\hline & $(1)$ & $(2)$ & (3) & $(4)$ & $(5)$ & (6) \\
\hline Female representation & $\begin{array}{c}0.009 * * * \\
(0.000)\end{array}$ & $\begin{array}{c}0.008 * * * \\
(0.000)\end{array}$ & $\begin{array}{c}0.005^{* * *} * \\
(0.000)\end{array}$ & $\begin{array}{c}0.006 * * * \\
(0.000)\end{array}$ & $\begin{array}{c}0.005^{* * *} \\
(0.000)\end{array}$ & $\begin{array}{c}0.004 * * * \\
(0.000)\end{array}$ \\
\hline Health spending & & & & $\begin{array}{c}0.047 * * * \\
(0.001)\end{array}$ & $\begin{array}{c}0.046 * * * \\
(0.001)\end{array}$ & $\begin{array}{c}0.027 * * * \\
(0.002)\end{array}$ \\
\hline Mother's education & & $\begin{array}{c}0.088 * * * \\
(0.003)\end{array}$ & $\begin{array}{c}0.068 * * * \\
(0.002)\end{array}$ & & $\begin{array}{c}0.081 * * * \\
(0.003)\end{array}$ & $\begin{array}{c}0.067 * * * \\
(0.002)\end{array}$ \\
\hline Age at birth: $<20$ & & $\begin{array}{c}-0.026 * * * \\
(0.004)\end{array}$ & $\begin{array}{c}-0.037 * * * \\
(0.004)\end{array}$ & & $\begin{array}{c}-0.028 * * * \\
(0.004)\end{array}$ & $\begin{array}{c}-0.035^{* * *} * \\
(0.004)\end{array}$ \\
\hline Age at birth: $40+$ & & $\begin{array}{l}-0.007 \\
(0.005)\end{array}$ & $\begin{array}{c}0.002 \\
(0.005)\end{array}$ & & $\begin{array}{c}-0.010 * \\
(0.005)\end{array}$ & $\begin{array}{c}0.001 \\
(0.005)\end{array}$ \\
\hline Male child & & $\begin{array}{c}0.002 \\
(0.002)\end{array}$ & $\begin{array}{c}0.002 \\
(0.002)\end{array}$ & & $\begin{array}{c}0.002 \\
(0.002)\end{array}$ & $\begin{array}{c}0.002 \\
(0.002)\end{array}$ \\
\hline SES2 & & $\begin{array}{c}0.014 * * * \\
(0.004)\end{array}$ & $\begin{array}{c}0.023 * * * \\
(0.003)\end{array}$ & & $\begin{array}{c}0.015 * * * \\
(0.004)\end{array}$ & $\begin{array}{c}0.022 * * * \\
(0.003)\end{array}$ \\
\hline SES3 & & $\begin{array}{c}0.029 * * * \\
(0.005)\end{array}$ & $\begin{array}{c}0.038 * * * \\
(0.004)\end{array}$ & & $\begin{array}{c}0.030 * * * \\
(0.004)\end{array}$ & $\begin{array}{c}0.037 * * * \\
(0.004)\end{array}$ \\
\hline SES4 & & $\begin{array}{c}0.040 * * * \\
(0.005)\end{array}$ & $\begin{array}{c}0.054 * * * \\
(0.004)\end{array}$ & & $\begin{array}{c}0.044 * * * \\
(0.004)\end{array}$ & $\begin{array}{c}0.053 * * * \\
(0.004)\end{array}$ \\
\hline SES5 (richest) & & $\begin{array}{c}0.051 * * * \\
(0.005)\end{array}$ & $\begin{array}{c}0.070^{* * *} * \\
(0.004)\end{array}$ & & $\begin{array}{c}0.062 * * * \\
(0.005)\end{array}$ & $\begin{array}{c}0.071 \text { *** } \\
(0.004)\end{array}$ \\
\hline Urban residence & & $\begin{array}{c}0.004 \\
(0.005)\end{array}$ & $\begin{array}{l}-0.002 \\
(0.004)\end{array}$ & & $\begin{array}{c}0.000 \\
(0.005)\end{array}$ & $\begin{array}{l}-0.002 \\
(0.004)\end{array}$ \\
\hline Year & & $\begin{array}{c}-0.003 * * * \\
(0.001)\end{array}$ & $\begin{array}{c}0.007 * * * \\
(0.001)\end{array}$ & & $\begin{array}{c}-0.009 * * * \\
(0.001)\end{array}$ & $\begin{array}{c}0.005 * * * \\
(0.001)\end{array}$ \\
\hline Extent of democracy & & & $\begin{array}{c}0.023 * * * \\
(0.001)\end{array}$ & & & $\begin{array}{c}0.020 * * * \\
(0.001)\end{array}$ \\
\hline Left party in power & & & $\begin{array}{c}-0.030 * * * \\
(0.006)\end{array}$ & & & $\begin{array}{c}-0.041^{* * *} \\
(0.006)\end{array}$ \\
\hline Log ODA & & & $\begin{array}{c}0.008 * * \\
(0.003)\end{array}$ & & & $\begin{array}{c}0.011 * * * \\
(0.003)\end{array}$ \\
\hline Log GDP pc & & & $\begin{array}{c}-0.133 * * * \\
(0.005)\end{array}$ & & & $\begin{array}{c}-0.113 * * * * \\
(0.006)\end{array}$ \\
\hline Log female labor force & & & $\begin{array}{c}0.121 * * * \\
(0.017)\end{array}$ & & & $\begin{array}{c}0.103 * * * \\
(0.016)\end{array}$ \\
\hline
\end{tabular}


Log female sec. GER

Region: LAC

Region: MENA

Region: SSA

Region: SE Asia

Region: South Asia
$0.035 * * *$

(0.006)

$-0.017$

(0.037)

$0.156 * * *$

(0.004)

$-0.280 * * *$

(0.031)

$-0.305^{* * * *}$

(0.060)

$-0.255^{* * *}$

(0.060)
$0.028 * * *$

(0.006)

$-0.076$

(0.043)

$0.151 * * *$

(0.004)

-0.270 ***

(0.031)

$-0.235^{* * *}$

(0.057)

$-0.180 * *$

(0.055)

\begin{tabular}{lllllll} 
Observations & 108,908 & 108,908 & 108,908 & 108,908 & 108,908 & 108,908 \\
\hline
\end{tabular}

Notes: Robust SEs in parentheses, clustered at the DHS sample cluster level; $* * * \mathrm{p}<0.001$, ** $\mathrm{p}<0.01, * \mathrm{p}<0.05 ;$ two-tailed tests. 
Table 7. Marginal effects from probit regressions of female representation dummies on infant death and measles vaccination outcomes, using both 51-country cross-sectional and 20-country longitudinal DHS data

\begin{tabular}{lccccc}
\hline & \multicolumn{2}{c}{ Infant death } & & \multicolumn{2}{c}{ Measles vaccination } \\
\cline { 2 - 3 } \cline { 5 - 6 } Variables & $\begin{array}{c}\text { Cross- } \\
\text { sectional }\end{array}$ & Longitudinal & & $\begin{array}{c}\text { Cross- } \\
\text { sectional }\end{array}$ & Longitudinal \\
\hline Female representation: $10-19.9 \%$ & 0.001 & -0.002 & & $0.172 * * *$ & $0.049 * * *$ \\
Female representation: $<20 \%$ & $(0.001)$ & $(0.002)$ & & $(0.004)$ & $(0.005)$ \\
& $-0.003 * *$ & $-0.013 * * *$ & & $0.170 * * *$ & $0.094 * * *$ \\
& $(0.001)$ & $(0.002)$ & & $(0.004)$ & $(0.004)$ \\
\hline
\end{tabular}

Notes: Robust SEs in parentheses, clustered at the DHS sample cluster level; *** $\mathrm{p}<0.001$, ** $\mathrm{p}<0.01, * \mathrm{p}<0.05$; two-tailed tests; results from the full models only, including health spending and all controls and region dummies. 


\section{Appendix}

Table A. Mixed-effects logistic regression of female representation (5-year lag) on infant death, using 20-country longitudinal DHS data time-indexed by child's birth year over 2000-2007

\begin{tabular}{|c|c|c|c|c|c|c|}
\hline \multirow[b]{2}{*}{ Variables } & \multicolumn{6}{|c|}{ Infant death } \\
\hline & (1) & (2) & (3) & (4) & (5) & (6) \\
\hline Female representation & $\begin{array}{c}-0.033 * * * \\
(0.006)\end{array}$ & $\begin{array}{c}-0.021 * * * \\
(0.006)\end{array}$ & $\begin{array}{c}-0.019 * * * \\
(0.006)\end{array}$ & $\begin{array}{c}-0.030 * * * \\
(0.006)\end{array}$ & $\begin{array}{c}-0.018 * * \\
(0.007)\end{array}$ & $\begin{array}{c}-0.017 * * \\
(0.006)\end{array}$ \\
\hline Health spending & & & & $\begin{array}{l}-0.024 \\
(0.021)\end{array}$ & $\begin{array}{l}-0.019 \\
(0.021)\end{array}$ & $\begin{array}{l}-0.021 \\
(0.020)\end{array}$ \\
\hline Mother's education & & $\begin{array}{c}-0.157 * * * \\
(0.019)\end{array}$ & $\begin{array}{c}-0.154 * * * \\
(0.019)\end{array}$ & & $\begin{array}{c}-0.157 * * * \\
(0.019)\end{array}$ & $\begin{array}{c}-0.154 * * * \\
(0.019)\end{array}$ \\
\hline Age at birth: $<20$ & & $\begin{array}{c}0.325 * * * \\
(0.033)\end{array}$ & $\begin{array}{c}0.324 * * * \\
(0.033)\end{array}$ & & $\begin{array}{c}0.325^{* * *} * \\
(0.033)\end{array}$ & $\begin{array}{c}0.324 * * * \\
(0.033)\end{array}$ \\
\hline Age at birth: $40+$ & & $\begin{array}{c}0.246 * * * \\
(0.048)\end{array}$ & $\begin{array}{c}0.247 * * * \\
(0.048)\end{array}$ & & $\begin{array}{c}0.246 * * * \\
(0.048)\end{array}$ & $\begin{array}{c}0.247 * * * \\
(0.048)\end{array}$ \\
\hline Male child & & $\begin{array}{c}0.220 * * * \\
(0.024)\end{array}$ & $\begin{array}{c}0.220 * * * \\
(0.024)\end{array}$ & & $\begin{array}{c}0.220 * * * \\
(0.024)\end{array}$ & $\begin{array}{c}0.220^{* * *} \\
(0.024)\end{array}$ \\
\hline SES2 & & $\begin{array}{l}-0.051 \\
(0.033)\end{array}$ & $\begin{array}{l}-0.051 \\
(0.033)\end{array}$ & & $\begin{array}{l}-0.051 \\
(0.033)\end{array}$ & $\begin{array}{l}-0.051 \\
(0.033)\end{array}$ \\
\hline SES3 & & $\begin{array}{c}-0.087 * \\
(0.036)\end{array}$ & $\begin{array}{c}-0.088^{*} \\
(0.035)\end{array}$ & & $\begin{array}{c}-0.087 * \\
(0.036)\end{array}$ & $\begin{array}{c}-0.088^{*} \\
(0.035)\end{array}$ \\
\hline SES4 & & $\begin{array}{c}-0.109 * * \\
(0.039)\end{array}$ & $\begin{array}{c}-0.111 * * \\
(0.039)\end{array}$ & & $\begin{array}{c}-0.109 * * \\
(0.039)\end{array}$ & $\begin{array}{c}-0.111^{* *} \\
(0.039)\end{array}$ \\
\hline SES5 (richest) & & $\begin{array}{c}-0.267 * * * \\
(0.050)\end{array}$ & $\begin{array}{c}-0.270 * * * \\
(0.050)\end{array}$ & & $\begin{array}{c}-0.267 * * * \\
(0.050)\end{array}$ & $\begin{array}{c}-0.271 * * * \\
(0.050)\end{array}$ \\
\hline Urban residence & & $\begin{array}{c}0.027 \\
(0.034)\end{array}$ & $\begin{array}{c}0.029 \\
(0.034)\end{array}$ & & $\begin{array}{c}0.026 \\
(0.034)\end{array}$ & $\begin{array}{c}0.029 \\
(0.034)\end{array}$ \\
\hline Year & & $\begin{array}{c}-0.040 * * * \\
(0.008)\end{array}$ & $\begin{array}{c}-0.021 * \\
(0.010)\end{array}$ & & $\begin{array}{c}-0.039 * * * \\
(0.008)\end{array}$ & $\begin{array}{l}-0.020 \\
(0.010)\end{array}$ \\
\hline Extent of democracy & & & $\begin{array}{l}-0.005 \\
(0.017)\end{array}$ & & & $\begin{array}{l}-0.003 \\
(0.018)\end{array}$ \\
\hline Left party in power & & & $\begin{array}{c}0.039 \\
(0.106)\end{array}$ & & & $\begin{array}{c}0.051 \\
(0.106)\end{array}$ \\
\hline Log ODA & & & $\begin{array}{l}-0.013 \\
(0.036)\end{array}$ & & & $\begin{array}{l}-0.015 \\
(0.036)\end{array}$ \\
\hline Log GDP pc & & & $-0.266^{*}$ & & & $-0.270 *$ \\
\hline
\end{tabular}




\begin{tabular}{|c|c|c|c|c|c|c|}
\hline & & & $(0.127)$ & & & $(0.125)$ \\
\hline \multirow[t]{2}{*}{ Log female labor force } & & & 0.061 & & & 0.037 \\
\hline & & & $(0.235)$ & & & $(0.232)$ \\
\hline Log female sec. GER & & & $\begin{array}{l}-0.203 \\
(0.108)\end{array}$ & & & $\begin{array}{l}-0.207 \\
(0.106)\end{array}$ \\
\hline \multicolumn{7}{|l|}{ Random-effects estimate } \\
\hline Country & $\begin{array}{c}0.463 * * * \\
(0.081)\end{array}$ & $\begin{array}{c}0.398 * * * \\
(0.069)\end{array}$ & $\begin{array}{c}0.215 * * * \\
(0.041)\end{array}$ & $\begin{array}{c}0.455 * * * \\
(0.080)\end{array}$ & $\begin{array}{c}0.393 * * * \\
(0.068)\end{array}$ & $\begin{array}{c}0.210 * * * \\
(0.041)\end{array}$ \\
\hline Observations & 152,804 & 152,804 & 152,804 & 152,804 & 152,804 & 152,804 \\
\hline
\end{tabular}

Notes: Unstandardized regression coefficients on the logit scale; random-effects estimate in SD

unit; SEs in parentheses; $* * * \mathrm{p}<0.001, * * \mathrm{p}<0.01, * \mathrm{p}<0.05$; two-tailed tests. 
Table B. Mixed-effects logistic regression of female representation (5-year lag) on measles vaccination status, using 20-country longitudinal DHS data time-indexed by child's birth year over 2000-2007

\begin{tabular}{|c|c|c|c|c|c|c|}
\hline \multirow[b]{2}{*}{ Variables } & \multicolumn{6}{|c|}{ Measles vaccination status } \\
\hline & (1) & (2) & (3) & (4) & $(5)$ & $(6)$ \\
\hline Female representation & $\begin{array}{c}0.030^{* * *} \\
(0.005)\end{array}$ & $\begin{array}{c}0.007 \\
(0.005)\end{array}$ & $\begin{array}{c}0.027 * * * \\
(0.007)\end{array}$ & $\begin{array}{c}0.033 * * * \\
(0.005)\end{array}$ & $\begin{array}{l}0.005 \\
(0.006)\end{array}$ & $\begin{array}{l}0.015^{*} \\
(0.007)\end{array}$ \\
\hline Health spending & & & & $\begin{array}{l}-0.021 \\
(0.019)\end{array}$ & $\begin{array}{c}0.018 \\
(0.019)\end{array}$ & $\begin{array}{c}0.077 * * * \\
(0.020)\end{array}$ \\
\hline Mother's education & & $\begin{array}{c}0.631 * * * \\
(0.014)\end{array}$ & $\begin{array}{c}0.633 * * * \\
(0.014)\end{array}$ & & $\begin{array}{c}0.631 * * * \\
(0.014)\end{array}$ & $\begin{array}{c}0.633^{* * *} \\
(0.014)\end{array}$ \\
\hline Age at birth: $<20$ & & $\begin{array}{c}-0.246^{* * * *} \\
(0.027)\end{array}$ & $\begin{array}{c}-0.247 * * * \\
(0.027)\end{array}$ & & $\begin{array}{c}-0.245^{* * *} \\
(0.027)\end{array}$ & $\begin{array}{c}-0.247 * * * \\
(0.027)\end{array}$ \\
\hline Age at birth: $40+$ & & $\begin{array}{c}0.015 \\
(0.039)\end{array}$ & $\begin{array}{c}0.018 \\
(0.039)\end{array}$ & & $\begin{array}{c}0.015 \\
(0.039)\end{array}$ & $\begin{array}{c}0.018 \\
(0.039)\end{array}$ \\
\hline Male child & & $\begin{array}{c}0.012 \\
(0.018)\end{array}$ & $\begin{array}{c}0.011 \\
(0.018)\end{array}$ & & $\begin{array}{c}0.012 \\
(0.018)\end{array}$ & $\begin{array}{c}0.011 \\
(0.018)\end{array}$ \\
\hline SES2 & & $\begin{array}{c}0.196 * * * \\
(0.024)\end{array}$ & $\begin{array}{c}0.195 * * * \\
(0.024)\end{array}$ & & $\begin{array}{c}0.196 * * * \\
(0.024)\end{array}$ & $\begin{array}{c}0.195^{* * *} \\
(0.024)\end{array}$ \\
\hline SES3 & & $\begin{array}{c}0.344 * * * \\
(0.027)\end{array}$ & $\begin{array}{c}0.344 * * * \\
(0.027)\end{array}$ & & $\begin{array}{c}0.344 * * * \\
(0.027)\end{array}$ & $\begin{array}{c}0.345^{* * * *} \\
(0.027)\end{array}$ \\
\hline SES4 & & $\begin{array}{c}0.506 * * * \\
(0.031)\end{array}$ & $\begin{array}{c}0.505 * * * \\
(0.031)\end{array}$ & & $\begin{array}{c}0.506^{* * * *} \\
(0.031)\end{array}$ & $\begin{array}{c}0.505 * * * \\
(0.031)\end{array}$ \\
\hline SES5 (richest) & & $\begin{array}{c}0.702 * * * \\
(0.040)\end{array}$ & $\begin{array}{c}0.699 * * * \\
(0.040)\end{array}$ & & $\begin{array}{c}0.702 * * * \\
(0.040)\end{array}$ & $\begin{array}{c}0.700 * * * \\
(0.040)\end{array}$ \\
\hline Urban residence & & $\begin{array}{l}-0.040 \\
(0.026)\end{array}$ & $\begin{array}{l}-0.039 \\
(0.026)\end{array}$ & & $\begin{array}{l}-0.040 \\
(0.026)\end{array}$ & $\begin{array}{l}-0.038 \\
(0.026)\end{array}$ \\
\hline Year & & $\begin{array}{c}0.094 * * * \\
(0.006)\end{array}$ & $\begin{array}{c}0.085^{* * *} * \\
(0.008)\end{array}$ & & $\begin{array}{c}0.094 * * * \\
(0.006)\end{array}$ & $\begin{array}{c}0.086 * * * \\
(0.008)\end{array}$ \\
\hline Extent of democracy & & & $\begin{array}{c}-0.100 * * * \\
(0.022)\end{array}$ & & & $\begin{array}{c}-0.100 * * * \\
(0.022)\end{array}$ \\
\hline Left party in power & & & $\begin{array}{c}0.045 \\
(0.110)\end{array}$ & & & $\begin{array}{c}0.050 \\
(0.110)\end{array}$ \\
\hline Log ODA & & & $\begin{array}{c}0.177 * * * \\
(0.027)\end{array}$ & & & $\begin{array}{c}0.188 * * * \\
(0.027)\end{array}$ \\
\hline Log GDP pc & & & $\begin{array}{c}-0.934 * * * \\
(0.206)\end{array}$ & & & $\begin{array}{c}-1.049 * * * \\
(0.207)\end{array}$ \\
\hline Log female labor force & & & $\begin{array}{c}3.110 * * * \\
(0.748)\end{array}$ & & & $\begin{array}{c}3.057 * * * \\
(0.744)\end{array}$ \\
\hline
\end{tabular}


Log female sec. GER

Random-effects estimate

Country
$0.490 * * *$

(0.121)

$0.898 * * * \quad 0.881 * * *$

(0.145)

(0.140)

$1.976 * * *$

(0.399)

$0.910 * * *$

(0.147)

$0.873 * * *$

(0.139)

$8 * * *$

(0.397)

Observations

108,908

108,908

108,908

108,908

Notes: Unstandardized regression coefficients on the logit scale; random-effects estimate in SD unit; SEs in parentheses; $* * * \mathrm{p}<0.001, * * \mathrm{p}<0.01, * \mathrm{p}<0.05$; two-tailed tests. 